as John Calvin and Jonathan Edwards, was based on idealistic philosophy. But in modern times it has drifted away from this foundation and out of its native air to a dualistic basis and into an uncongenial atmosphere that have involved it in grave difficulties. By thrusting an opaque world between God and man it has, in a measure, screened God off from us and made him seem remote and inaccessible, whereas the Bible and the old theologians bring God near and make him vital and warm to us, our very breath and life. Theology is necessarily conservative, but it is now responding to the great idealistic move- ment that set in with Descartes and Kant and is being quickened in this more genial air. Skepticism, that found such a vulnerable part in dualism, is being met with a more solid front and matched with keener weapons. All the doctrines of Christian theology are being restated in the light of monistic philosophy, and they are more deeply and rationally grounded, cohere in a stronger system, and are enhanced in power as integral parts of the spiritual world-order. Our whole modern thinking is being permeated and molded by the idea of the divine immanence, and this is the root of idealism.

\title{
A NEW PIETY
}

\author{
ROSS W. SANDERSON \\ Sandusky, Ohio
}

Time was when men were attractively pious. To be pious these days is to be the butt of ridicule. What some folks call piety seems to us as despicable as the humility of that very 'umble man, Uriah Heep. Such piety is pharisaical. It deserves in our day all the scorn that Jesus heaped upon the hypocrisy of the scribes. Yet there is a true piety. It is the same in all ages. For the sake of accuracy in thinking and fairness of speech we sometimes call this spurious pseudo-piety not piety at all, but mere "piosity." Possibly the word doesn't exist in the dictionaries, but it is convenient.

Now our recent "piosity" is subject to three indictments. Let us take up the counts in order.
Our traditional piety is to be arraigned on the charge of being formal, individualistic, and nationalistic.

It is formal. To be pious, in the old sense, you must say your prayers at bedtime and when you rise. To be pious you must have a certain type of family worship. To be pious you must observe the Sabbath in a sort of woebegone, sanctimonious fashion. Now a regular time of prayer is good-but how how about those who travel on trains? Ask any missionary secretary how he says his prayers in a Pullman car. Ask the honest minister whether he finds it altogether easy to maintain family worship. At night the children are in bed or ought to be. Frequently the minister isn't home for the evening meal. 
The noon hour is impossible. In the morning breakfast is necessarily late, and school time is early. The youngsters are eager to be off. Life has become secularized. Is it any the less sacred?

The old piety was individualistic. On Sunday we were allowed to pop a little corn, perhaps, and the chickens were permitted to roam the wide lawn -but we couldn't go beyond the gate. Meanwhile the great crowd of so-called worldlings enjoyed itself. We complimented ourselves on our superior sanctity. We drew up our skirts in fear lest we be besmirched by the wordliness of the crowd. Verily, we were religious. Meanwhile slums sprang up, child labor became established, the hours of women employees were villainous, liquor intrenched itself in politics, graft ran riot through our municipal governments, competition became cut-throat, and class war rumbled along the economic horizon. As for us, we went to church and Sunday school. We were religious. It was very sad that the world was so wicked. We kept ourselves unspotted from the world.

The old piety was-nay, it isnationalistic. What is the tragedy of Europe today? It is not its economic loss-fearful as that is. It is not its animal slaughter-terrific as is the carnage. It is not the ambition of the warlords, or the heartlessness of the gunmakers, or the feebleness of the diplomatists, or the sorrows of the helpless. The tragedy of Europe is its travesty of Christian piety. We thought we were getting on a New Testament basis. We have gone back to the days of the conquest of Canaan. England prays for the destruction of her enemies and sings "God save the King"; and the Kaiser answers, "And we battle for the Lord." Night and day the prayers of the French rise to the high heaven - "Save us, 0 Lord, and avenge us upon our enemies." And my German Lutheran colleague across the street has no other explanation for the falling back of the Germans from Paris than to declare that it was because "the Lord let the rains come." I do not know what you call this. I call it patriotism reduced to an absurdity. I call it the breakdown of the old piety. I call it a tragedy or a joke. It is like children in the midst of their fisticuffs squalling out, "Mama, he hit me first!" I think Jehovah would laughwere not the wounds of his children so sore. Just this, we discover, Alfred Noyes had in mind when he wrote in The Wine Press about that relatively diminutive affair, the Balkan War.

Then, on the cross of His creative pain,

God bowed His head again.

Then East and West, over all seas and lands,

Out-stretched His piercèd hands.

Then, down in hell, they chuckled, "West and East,

Each holds one hand, at least."

"And yet," Sandalphon whispered, "men deny

The eternal Calvary."

Now the new piety must be a matter of the heart, of the very spirit of a man's life. It is not in the crook of the knee or in the movement of a finger that we acknowledge the grip of God upon us. It is not in a stated hour, or a set form, any more than it is in Jerusalem or some Samarian mountain, that we must worship him. We must worship him in spirit and in truth. Jesus probably said his prayers as a boy, but the fact 
is not recorded. It is recorded that he prayed. God help us to pray, to make life itself, and not some formal moment of it, a prayer to the unfailing Father, a silent, uninterrupted attestation to our continuing comradeship with him.

The new piety must be socialized. No man liveth to himself. No man can be pious to himself. There is no such thing as individual piety. The rankest individualist must admit the social basis of individuality itself. When ye pray, say ye, Our Father.

Life is all of a web. Sewers and outhouses and cowsheds and street pavements and fire-escapes and housing problems and tuberculosis sanitoria and playgrounds, the crusade against alcohol, the hearty, fraternal, brotherly spirit toward friend and foe, the cordial handclasp for the saloonkeeper, the jolly "good morning" to his little lad, the firm but tender kindness to the streetgirl-we must be big enough to pray and to work in reference to all these things before ever we dare call ourselves pious. And, by the way, it is a good rule to discount pretty heavily the piety of a man who acknowledges that he is pious. Real piety is a rare and precious commodity in this good year of our Lord I9I5.

The new piety must be more than patriotic. It must think in terms of the Kingdom. The field is the world. There is no smaller field. We pastors work in the world. We do not work in our little communities. Our job is the Kingdom-nothing less. Just now we hoe in some particular row. But these are Kingdom-tasks that we perform, or they are sounding brass or clanging cymbal. We must somehow transmute the little patriotisms of today into a passion for the Kingdom of God. We are on the threshold of a something called world-civilization. We must have it-if for no other reason than that the great missionary enterprise has forced it upon us. All lines of race and clan, all demarkations of river and mountain are becoming mere sectional names, intellectual conveniences, tags to label the differently located portions of humanity. It is all God's family. If there is any such thing as piety it must include in its emotion, in its surging vision, in its high resolves-not me and mine alone, but God and all God's children everywhere. For he hath "made of one every nation of men to dwell on all the face of the earth."

Now we must have this new, bigger, broader, finer piety. I have hinted that the missionaries have been silently forcing it upon us. In a way, the task of the home church these days is simply to catch up with the Kingdom-vision of the real missionary.

But the new piety is being demanded from quite another quarter. Study the great social movements of today. Take socialism. Much of it is godless. Many socialists imagine that they have manifestoed God out of existence. But God is big enough and patient enough to be inspiring even those who scorn him. There is in socialism a great tidal force, only beginning to gather strength, and it is making toward the shores of peace. "I am very jealous for the Lord God of Hosts." I am ashamed of the Christian church. Shall we allow labor in the name of shekels to stop war? Or shall we proclaim peace in the name of the Prince of Peace? If we are to do this 
we must have a new piety, a firmer, wider-visioned, more brotherly piety than the old, tribal, class-conscious, patronizing piety of yesterday.

And who started the altruistic institutions of Christendom - the social settlement, the charity organization society, and all the rest? Mostly church folks, of course. But it was not their piety or the piety of the church that impelled them. It was their revolt against the formalism, the individualism, the trammels of race and clan that fettered all ecclesiasticism. Now the pendulum is swinging back. Social service is realizing that it must be religious, that it has been religious. And the church is seeing the gleam and is about making up its mind to follow it. Rauschenbusch writes his prayers. To the man with imagination the issuing of that little volume marks an epoch in the history of the church.

There is a charming comedy by Josephine Preston Peabody called The Wolf of Gubbio. It opens with a singular prologue, only these words:

San Francesco!

San Francesco!

-D'Assisi!

-D'Assisi!

-D’Assisi!

But brief as it is, that prologue takes you back instantly, with a sort of mystic swiftness, to the time seven hundred years ago, when the figure of St. Francis dominated the ecclesiastical landscape. It is as if some fairy record-maker and some skilful photographer out of the dreamland of the past had entered into a benevolent conspiracy to give us the ringing voice and the living figure of "the Little Poor Man" who walked the world-and

Hunger, and thirst, and lack, and loss, Beckoned to him as stars.

In his day he preached a new piety. We need now in some new fashion, with a different emphasis, something of the dominant leadership of a man like Francis of Assisi. In their day Luther and Calvin and Wesley-great worldleaders all of them-preached a new piety. If we have historical perspective enough in our imagination we shall see in men like Rauschenbusch the forerunners of another great world-leader of religion. He is coming, this new world-leader. The world awaits him. The world needs him. When at last he really comes, he too will preach a new piety. For from time to time we need a new piety. Now is such a time.

The other day a cathedral, pure Gothic, was at least partially destroyed. Eight centuries ago they began the building of it. Bishops dreamed and architects planned and workmen executed. It was the century-long expression of a vital piety. In the choir of that cathedral countless voices have chanted the solemn hymns of the church. Under the roof of its nave, standing in its transepts, myriads of worshipers have felt the solemn awe of a noble worship. There was poetry there, it was carved into the very capitals of the piers. There was consecration, ignorant, blind, but loyal. You trace it in the very gargoyles.

That was long ago. That impulsearchitectural-has spent itself. Men like Walter Rauschenbusch are pioneers 
in a new piety. There are new structures to be reared. There is a new ritual to be written. There are new songs to be sung. The time is at hand, but it is not yet fully come. We must first have, in the many and in the few, a new piety. Then God give us men with pens dripping with the blood of human hearts; God give us poets with a song like Washington Gladden's; God give us musicians to teach us how to sing the songs of the Kingdom.

o Master, let us walk with thee In lowly paths of service free-- this is the new piety which we have been singing for a generation. But we have only begun to be pious. When we understand what piety means we shall have a new hymnology, a new ecclesiasticism, a new civilization-we shall have come into the Kingdom.

Doubtless we shall never have any real piety until the simple, natural, Godloving Man of Nazareth comes wholly into our lives. Doubtless he will have to come in and abide with us and show us how, before ever the world shall learn the secret of piety. Even so, come, Lord Jesus.

\title{
THE RELATION BETWEEN THEOLOGY AND SOCIOLOGY
}

\author{
E. GUY TALBOTT \\ Executive Secretary, Church Federation of Sacramento, California
}

Theology is the science of man's relation to God; sociology is the science of man's relation to his fellow-men. The corollary of the doctrine of the fatherhood of God is the doctrine of the brotherhood of man. From the ethical or scientific viewpoint, man's relation to his Father is intimately connected with his relation to his brother. Theology and sociology are, therefore, complementary.

Man is not right with God who is not also right with his fellow-man. Holiness toward God presupposes righteousness toward our fellow-men. The man who "walks humbly with God" must also "deal justly" and "love mercy."
The Old Testament commandments have to do, first, with man's relation to God; secondly, with man's relation to his fellow-man. One of the tables is of equal importance with the other. Under the Mosaic Code, theology and sociology are inseparable.

Christ, likewise, gave two commandments, the first defining man's attitude toward God, the second his attitude toward his fellow-men. Christ said: "He that loveth God, let him love his brother also." And again: "If a man say that he love God, and hateth his brother, he is a liar," said John. Christ, who spoke of himself as the Son of God, spoke also of himself as the Son of Man. 